\title{
Analysis of Tropical Forest Landscape Fragmentation in Batang Toru Watershed, North Sumatra
}

\author{
Samsuri $^{1 *}$, I Nengah Surati Jaya ${ }^{2}$, Cecep Kusmana ${ }^{3}$, Kukuh Murtilaksono $^{4}$ \\ ${ }^{1}$ Department of Forestry, Faculty of Agriculture, Sumatra Utara University, Medan, J1. Dr. T. Mansur No. 9, Medan, \\ Indonesia 20155 \\ ${ }^{2}$ Department of Forest Management, Faculty of Forestry, Bogor Agricultural University, Academic Ring Road, Campus IPB \\ Dramaga, PO Box 168, Bogor, Indonesia 16680 \\ ${ }^{3}$ Department of Silviculture, Faculty of Forestry, Bogor Agricultural University, Academic Ring Road, Campus IPB Dramaga, \\ PO Box 168, Bogor, Indonesia 16680 \\ ${ }^{4}$ Department of Soil Science, Faculty of Agriculture and Land Resources, Bogor Agricultural University, Academic Ring Road, \\ Campus IPB Dramaga, Bogor, Indonesia 16680
}

Received May 4, 2014/Accepted July 20, 2014

\begin{abstract}
Timber-based forest management is now shifting to as broader scope including ecosystem-based management. Timber-oriented forest management frequently affects the fragmentation of forest landscape. This paper defines the degree of forest landscape fragmentation in Batang Toru watershed, North Sumatra through indentification of correlation between forest landscape fragmentation and driving factors including biophysical and anthropogenic factors. Identification structure, pattern, and fragmentation of forest landscape were performed using Landsat imageries acquired in 1989, 2001, and 2013. Forest and land cover classes were analyzed using FRAGSTAT 3.3 to generate landscape metrics. Fragmentation of forest landscape was identified using landscape metrics, i.e., area, patch density, number of patch, contiguity and proximity index. The clumpiness index of landscape metrics describes the pattern of forest landscape, while the patch size proportions expressed structure of forest landscape. This study found that forest landscapes located in downstream of the watershed show more fragmented than area in the upper stream, while the sub-watershed of Batang Toru Hilir is more clumped than the others. This study concludes that (1) the forest landscape fragmentation tend to increase since 1989 to 2013; and (2) the degree of forest landscape fragmentation has close correlation with the distance to main road and river.
\end{abstract}

Keywords: forest connectivity, ecosystem, deforestation, fragstat, fragmentation

*Correspondenceauthor,email: gsamsuri@gmail.com,tel.:+62-8561033832

\section{Introduction}

Forest management solely oriented on wood is increasingly irrelevant to the function of forest as broader ecosystem. Tropical forest fragmentation has triggered the decline of forest ecosystem function including hydroorological and the biodiversity conservation functions. Monitoring of forest landscape fragmentation is required to develop strategy on managing the remaining forest landscape. One of the most important of ongoing process of natural landscape fragmentation is forest degradation (Batistella et al. 2000). ITTO/IUCN in 2005 stated that landscape of world's tropical forests remain $45 \%$, which are in separately forest block (fragmented) and damaged condition. Forest degradation in tropical rain forest areas reduced global biological resources (CBD 2005), and has an impact on occurrence of poverty in communities in and around the degraded forest (Lamb et al. 2005).

Deforestation can increase forest fragmentation (Reddy et al. 2013; Newman 2014). Fragmentation of the landscape may have severe consequences for forest biota, including loss of suitable habitat for sensitive species (Mendoza et al. 2005), increasing competition from generalist species (Laurance et al. 2009) and genetic isolation of sub population (Goosem 2007), all of which may ultimately result in local extinction of native forest dependent species (Laurance et al. 2009). Fragmentation is one of single most important factor trigering to the loss of biodiversity in forest landscape (Fahrig 2003). Several species have been predicted to be highly vulnerable due to habitat fragmentation result (Bradsaw \& Marquet 2003). The process of habitat fragmentation result in increased patch isolation together address quantitative measure of fragmentation. Increasing trend of fragmentation is of major interest in biodiversity, conservation biology, ecology, forestry and biogeography. Landscape fragmentation break up of continous of habitat into small; less connected patches can drive devastating and irreversible consequences on the regional biodiversity. Previous research had been proven that forest fragmentation 
may cause biodiversity loss (Priatna et al 2012). Landscape connectivity is a major concern in the maintenance of wildlife population and is considered important for ecological processes such as movement of gene, individuals, species, and population over multiscale, especially in fragmented landscape.

Fragmentation analysis involved the use of statistical measures called metric or indices that describe the landscape composition and configuration. Examine the composition and configuration of landscape can be used to monitor the ecological process which can help forest landscape management. Quatification and comparison of landscape indices have been proven as the most effective method on the analysis of forest fragmentation (Garcia 2004; Li et al. 2009; Singh et al. 2010).

Forest of Batang Toru watershed is the remaining tropical forest ecosystem in North Sumatra that suffer from high environmental pressure due to open access condition which led to forest encroachment and deforestation. Furthermore, forest degradation and deforestation may enhance erosion and landslide hazard. Hence, the erosion sediment was carried out into reservoir that has been determined as a source of generating electricity power. Community surrounding forest area has been suffered from direct impact of forest degradation due to water debit deficiency and land degradation. Due to the strategic function of Batang Toru ecosystem, proper management is required. This can be obtained from this study, which aimed to examine pattern and structure of forest landscape, and develop index of forest landscape fragmentation in Batang Toru watershed as well as to identify factors triggering fragmentation of forest landscape.

\section{Methods}

The study was conducted in Batang Toru watershed, North Sumatra Province, Indonesia (Figure 1). It comprises of three sub-watersheds namely Batang Toru Hilir, Puli, and Sarula sub watersheds. Batang Toru Hilir is located in downstream of watershed while Puli and Sarula subwatershed are in upperstream of watersheds. The research have been conducted within September 2013 until January 2014. The watershed cover area about 203,445 ha and located between $\mathrm{N} 1^{\circ} 10^{\prime} 36.47^{\prime \prime}-1^{\circ} 10^{\prime} 36.60^{\prime \prime}$ and E98 ${ }^{\circ} 23^{\prime}$ $48.22^{\prime \prime}-98^{\circ} 49^{\prime} 15.00^{\prime \prime}$. The research site cover area about 203,782 ha on elevation ranged from aproximately 0 to 2,000 $\mathrm{m}$ asl. Batang Toru forest has biodiversity richness as a home of thousand species of flora and fauna such as 67 mammals species, 287 birds species, 110 species of herpetofauna and 688 plant species (Perbatakusuma \& Damanik 2011).

The main data used in this study were Landsat imageries to derive land covers and land uses from 1989 to 2013. The use of such historical data is important for development of conservation strategy and demonstrated of long term pastantropogenics impact (Thompson et al. 2002). The images were dowloaded from http://glovis.usgs.gov. The images used are Landsat TM 1989, Landsat ETM 2001, and Landsat 8 OLI 2013. Image pre-processing and processing was done using Erdas Imagine 9.1.

The satellite images were analysed to produce land cover (use) map. The land use classes (categories) referred to the category of Ministry of Forestry. Field surveys were conducted to verify landscover types and to measure the vegetation parameter i.e. diameter, height, and number of tree. The sampling plots (140 plots) were laid using sistematics sampling with random start. Besides, maps of

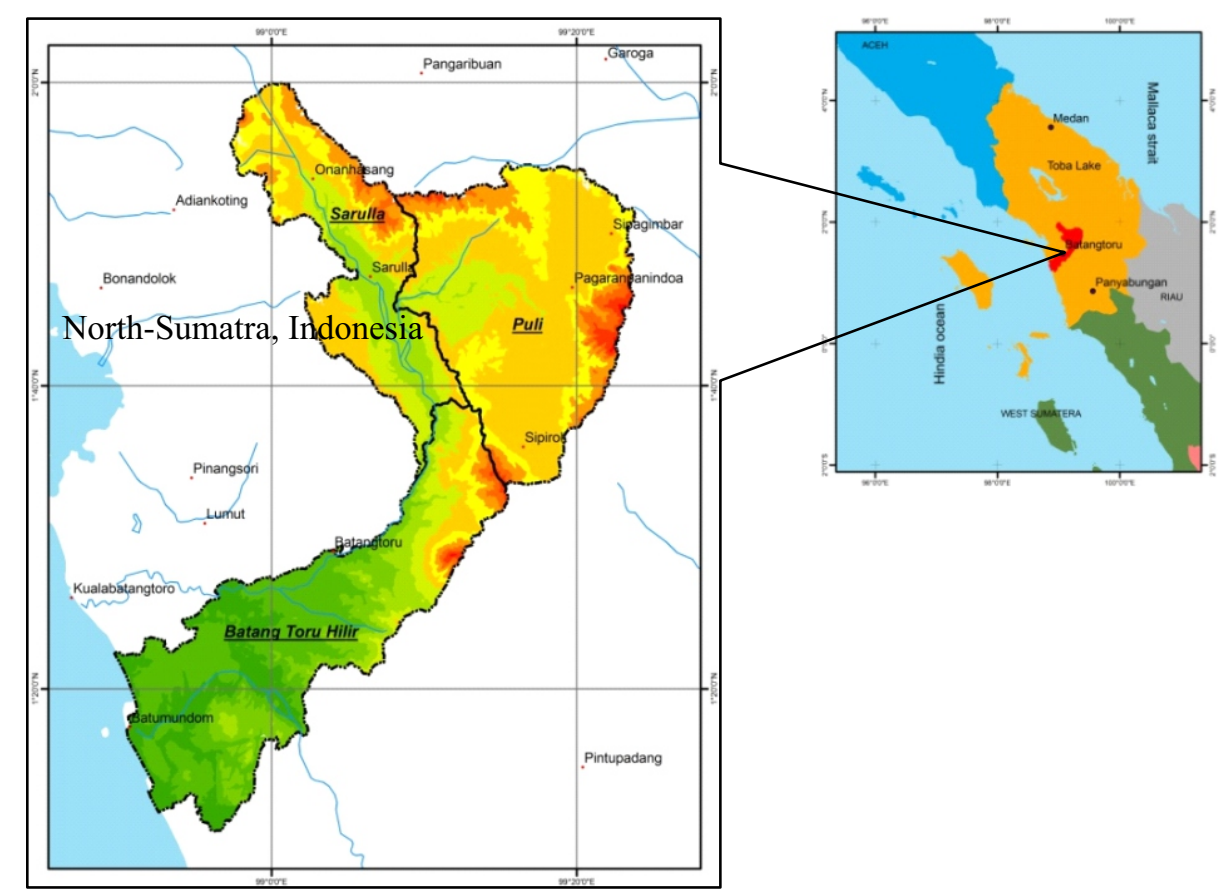

Figure 1 Research site in Batang Toru Watershed, North Sumatra, Indonesia. 
watershed boundary, river, administration, road, and other thematic maps were also collected. Other secondary data used were population data which were provided by Indonesia Statistical Data 2011. Erdas Imagine 9.1 is used to interpretate satellite imagery, Arc GIS 9.3 to conduct spatial analysis, Fragstats 3.3 (McGarigal \& Marks 1995) is used to examine landscape metrics, and Microsoft Excel is used to calculate statistic.

The process of data analysis was illustrated in Figure 2. Satellite images classification were performed using supervised method. Accuracy assesment were conducted by comparing the result of classification with independent ground survey data sources. The sources included GPS points collected in the field during the field survey and reference map. Accuracy measures used are overall accuracy and Kappa accuracy (Jaya 2009). The accuracy evaluation was conducted using 140 ground truth points collected in the field to asses the accuracy of the classified 2013 landsat image. The accuracy assessment of the classified 1989, and 2001were done using landcover map made in 1990 and 2000 by the Ministry of Forestry at a scale of 1: 250,000. The clasified images were converted into grid files in ArcGIS 9.3. Landcover type of the forest was then analyzed using Fragstats to produce landscape metrics. Landscape metrics produced from fragstat analysis are area, patch density, number of pacth, proximity and contiguity index. They become fragmentation landscape forest (FLF) indicators. The FLF degree was calculated based on landscape metrics, which include size, shape, density, and isolation of forest area.

Vegetation data from the field survey were analyzed to obtain the index value richness, basal area and tree density (Cox 1985; Krebs 1989; Kusmana 1997). Social data collected from PODES data is interpolated to obtain spatial distribution. PODES data is the village potential statistics dataset which provide information about village characteristics for all of Indonesia. The landscape metrics used in the study area were area, number of patch, proximity index, patch density index and contiguity index as described in Table 1 (McGarigal \& Marks 1995; McGarigal et al.

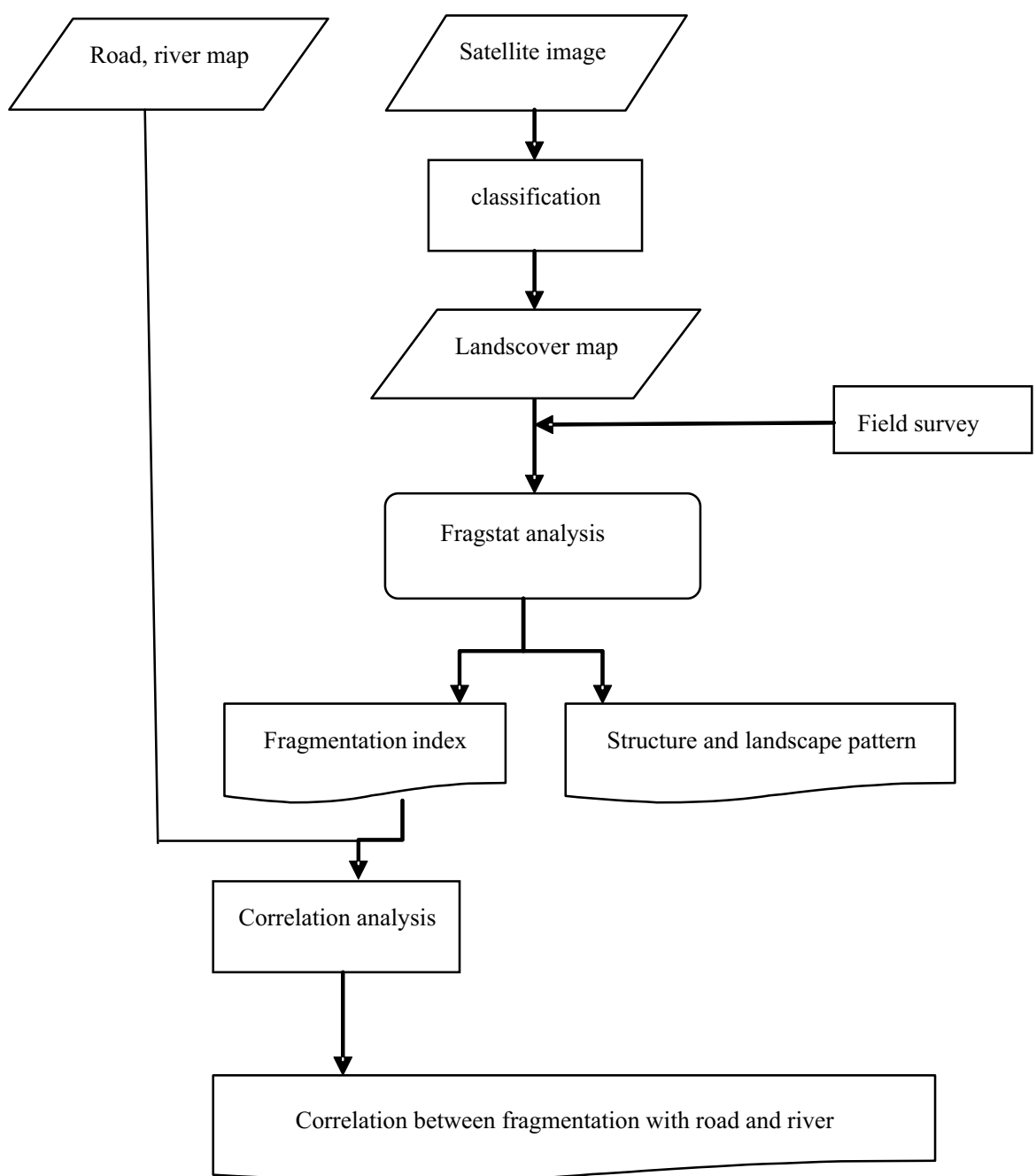

Figure 2 Data analysis process. 
Table 1 Landscape indices use for spatial pattern analysis of forest fragmentation (McGarigal \& MArks 1995). Full definition are provided at $h t t p / /: w w w . u n m a s . e d u / l a n d e c o / r e s e a r c h / f r a g s t a t / f r a g s t a t . h t m l>$

\begin{tabular}{|c|c|c|}
\hline Metric & Code & Description \\
\hline Patch area & Area & AREA equals the area (m2) of the patch, divided by 10,000 (to convert to hectares). \\
\hline Patch density & PD & The number of forest patches per 100 ha \\
\hline Number of patches & NP & $\begin{array}{l}\text { The total number of forest patches in the landscape. It is average of a pacth of a particular } \\
\text { class. It depend on data resolution; sensitive class to addition/deletion of small patches. } \\
\text { Mean patch size can serve as a habitat fragmentation index }\end{array}$ \\
\hline Proximity & PROX & $\begin{array}{l}\text { The tendency for patches to be relatively isolate d space (i.e. distance) from other patch of } \\
\text { the same or similar ecology friendly class }\end{array}$ \\
\hline Contiguity index & CONTIG & $\begin{array}{l}\text { Measure of spatial connectedness of individual forest patches to other forest patches. } \\
\text { Increasing value indicate increasing of connectedness. }\end{array}$ \\
\hline
\end{tabular}

2002). Landscape pattern was determined using clumpiness index. It was calculated using Equation [1] (McGarigal et al.2002). While landscape structure was determined by the proportion of patch area in the forest landscape (Forman \& Godron 1986).

$$
\text { Given } G_{i}=\left[\frac{g_{i i}}{\sum_{k=1}^{m} g_{i k}}\right]
$$

$$
\text { clumpiness } \left.=\left[\begin{array}{lc}
\frac{G_{i}-P_{i}}{1-P_{i}} & \text { for } G_{i} \geq \mathrm{P}_{\mathrm{i}} \\
\frac{G_{i}-P_{i}}{1-P_{i}} & \text { for } G_{i}<P_{i} ; P_{i} \geq 5 \\
\frac{P_{i}-G_{i}}{-P_{i}} & \text { for } G_{i}<P_{i} ; P_{i}<5
\end{array}\right\}\right]
$$

note:

$g_{i i}=$ number of like adjacencies (joins) between pixel of patch type (class) $i$ based on the double-count method

$g_{i k}=$ number of adjajencies (joins) between pixel of patch types (classes) $i$ and $k$ base on the double-count method

$P_{i}=$ proportion of the landscape occupied by patch type (class) $i$

Each of landscape metrics was then classified and scored to determine the degree of forest landscape fragmentation. The scoring was based on Likert scale basis. The total score was calculated by algebra sum of the score as shown in Equation [2]. Weighted of each landscape metric was determined using PCA analysis. Further, the total score was converted into value between 0-1 using Equation [3] (Jaya et al. 2007; Orsi \& Geneletti 2010).

$$
W_{f g}=\sum_{i=1}^{n} w f g_{i} \times f f g_{i}
$$

note:

$W f g=$ total score of fragmentation

$w f g_{i}=$ score of landscape metric- $i$

$\mathrm{ffg}_{i}=$ weighted of landscape metric-ii

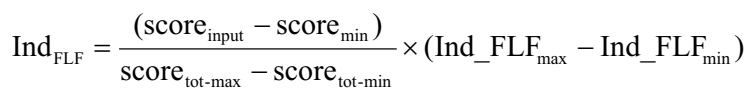

note:

$\operatorname{Ind}_{\mathrm{FLF}} \quad=$ index value of forest landscape fragmentation

Score $_{\text {input }}=$ total score as input

Score $_{\text {tot-min }}=$ minimum value of total score

Score $_{\text {tot-max }}=$ maximum value of total score

Ind $\mathrm{FLF}_{\text {max }}=$ maximum index of forest landscape fragmentation (converted value)

Ind $\mathrm{FLF}_{\min }=$ minimum index of forest landscape fragmentation (converted value)

Pearson correlation analysis was conducted to examine correlation between the FLF index with distance to main road, distance to river, degree of slope, and elevation. The index value of forest landscape fragmentation then is classified into 3 classes with range index value of each class. The range of FLF index are low FLF ( $0-0.4$ index value), moderate FLF (0.41-0.6 index value), and high FLF (0.61-1 index value). The index of FLF is used to develop the degree of FLF map.

\section{Results and Discussion}

Pattern and structure of forest landscape Spatial distribution pattern of forest landscape is indicated by clumpiness index. Figure 3 a shows clumpiness index tend to be decreased within 1989-2013. Otherwise, clumpiness index of Sarula sub watershed increased in 2001. Forest landscape pattern of Batang Toru watershed is more clustered than other sub watershed. Meanwhile, forest landscape of Puli sub watershed is more scatered relatively. Batang Toru Hilir has human activties more masive than Puli sub watershed. It have been proved by Miyamoto and Sano (2008) that landscape structure changed in response to human activities (Gounaridis et al. 2014). Forest landscape of Batang Toru Hilir watershed is remained in hill and mountain area. This result inline with the reseacrh conducted by Zhang et al. (2010) that found the forest landscape tend to be clustered in hill and mountained area.

Forest landscape structure encompasses the relation of ecosystem componen (Forman \& Godron 1986). Proportion of forest patch number based on their area can descript the forest landscape structure. Figure $3 \mathrm{~b}$ shows the highest proportion of forest patch area belong to ranged of $0-1,000$ ha. While, the biggest forest patch have area about $12,000-13,000$ ha. It is located in Puli sub watershed. It shows forest landscape structure is more compact due to 

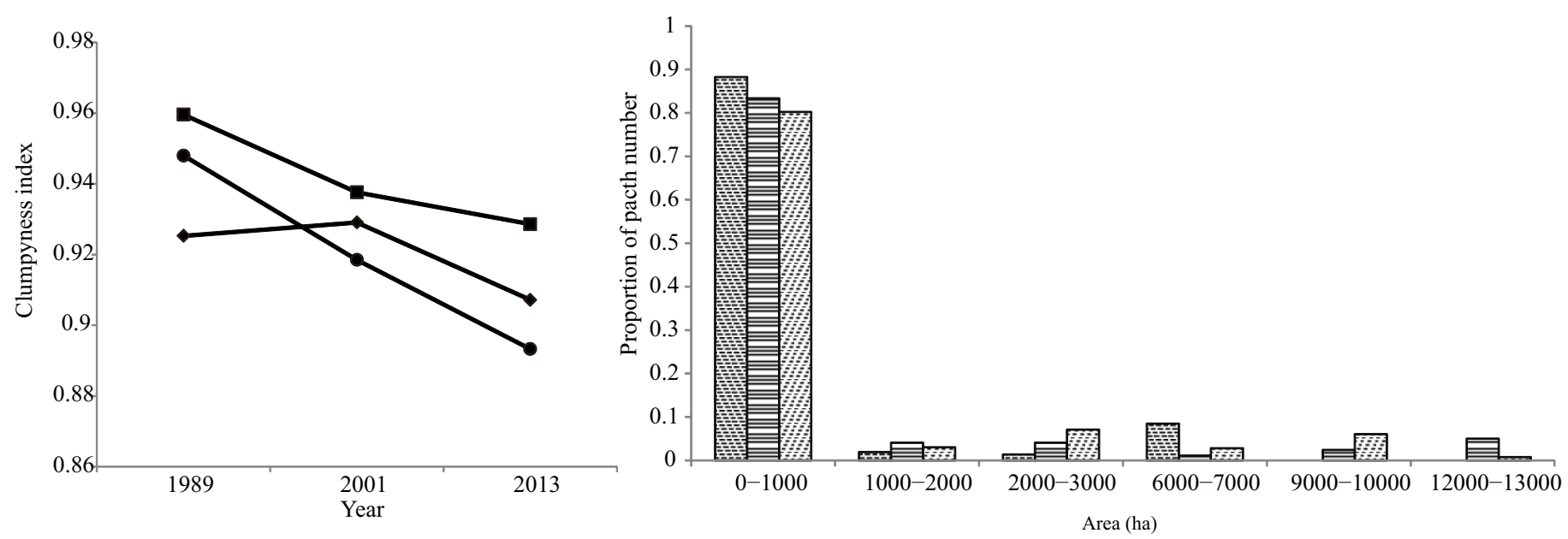

Figure 3 Trend of landscape pattern (a) and landscape structure (b) of forest in Batang Toru watershed. Puli $=(\rightarrow-$, , 目), Sarula $(\rightarrow \infty$, 园), Batang Toru Hilir ( - -, 国)

having bigger forest patches. The otherway, forest landscape of Batang Toru Hilir is less compact than other. Bigger forest patches is found in upstream of sub watershed while smaller forest patches located in downstream of sub watershed. Upper part of each sub watershed is in the area which has highest elevation and slope relatively. So, the forest landscape did not get any disturbance caused by worst accessibility (Cabral et al. 2007). This is inline with Wu et al. (2014) state that road contruction and urbanization result fragmentation and landscape pattern (Matsushita et al. 2005).

Forest landscape fragmentation (FLF) of Batang Toru 1989-2013 Forest landscape metrics of year 1989, 2001, and 2013 showed that patch density tend to increase during 1989-2013 (Figure 4a). Otherwise, the contiguity index tend to decrease along 1989-2013 as depicted on Figure $4 \mathrm{~b}$. It means that the FLF is increased. It is caused by the increase of population and land needed to be cultivation on the forest area. Batang Toru Hilir and Sarula watershed were experienced decreasing of contiguity and proximity index within 1989-2013. Defferent condition in sub watershed of Puli experienced with increasing of contiguity index during 1989-2001 (Figure 4b), and also increasing of proximity index during 1989-2001 (Figure 4c). Yet, both of contiguity and proximity index of Puli sub watershed decresed in 2013. It means that the FLF of Puli sub watershed is increased in 2013.

Based on map of landscape metrics and map of watershed boundary, it is found that downstream of watershed have the most of patch number. Batang Toru Hilir sub watershed has the highest patch density as shown in Figure 4a. Human activities in downstream of watershed is higher than the other part of watershed. It affect the degree of forest fragmentation in downstream of watershed. The highest patch density has been caused by forest fragmentation in downstream of watershed. Small patch size shows that forest landscape is more isolated and more fragmented (Forman \& Godron 1986; Forman 1995). It is found increasing the number of forest patch (forest patch density) over time toward (Giordano \& Baccone 2010). It will reduce large area of forest patch, then increasing in isolation of forest patch and declining of forest connectivity. Figure $4 \mathrm{~b}$ shows that the forest of Batang Toru Hilir sub watershed is more fragmented. The fragmentation in the sub-watershed has been caused by relatively high population density of Batang Toru Hilir of 50-250 individuals (or people) per $\mathrm{km}^{2}$ (BPS 2011). The FLF is positively related to the degree of urbanization (Weng 2007). Increasing population density is leading to increase of fragmentation (Gonzalez-Abraham etal. 2007).

Correlation between FLF index with biophysical and antrophogenic factor Human disturbance factors influence on decreasing connectivity of forests as natural habitats (Liu et al. 2014), as well as the slope and elevation factors (Simone et al. 2010). Ongoing anthropogenic factor can influence structure and composition of forest landscape which borders other uses (Hardt et al. 2013). Pearson correlation between fragmentation index and distance to roads showed that the farther distance to the road, the lower forest landscape fragmentation index, otherwise getting close to the main road, the higher of landscape fragmentation index (Table 2). It shows humans tend to cause fragmentation in the area which is close to the road (Newman et al. 2014), and has better forest accessibility (Nagendra et al. 2003; Shearman et al. 2009). Increasing of human population increased the fragmentation. Fragmentataion can change the forest landscape structure that can reduce the environment quality (Matsusita et al. 2004). The other research shows the primary direct cause are economic driven intense anthropogenic activities (Gounaridis et al. 2014).

High correlation between fragmentation index and distance from forest to the river was found in Batang Toru Hilir sub-watershed, higher than that occurred in other subwatershed. The farther of distance to the river, the lower of FLF index, and inversely the closer the distance to the river, 

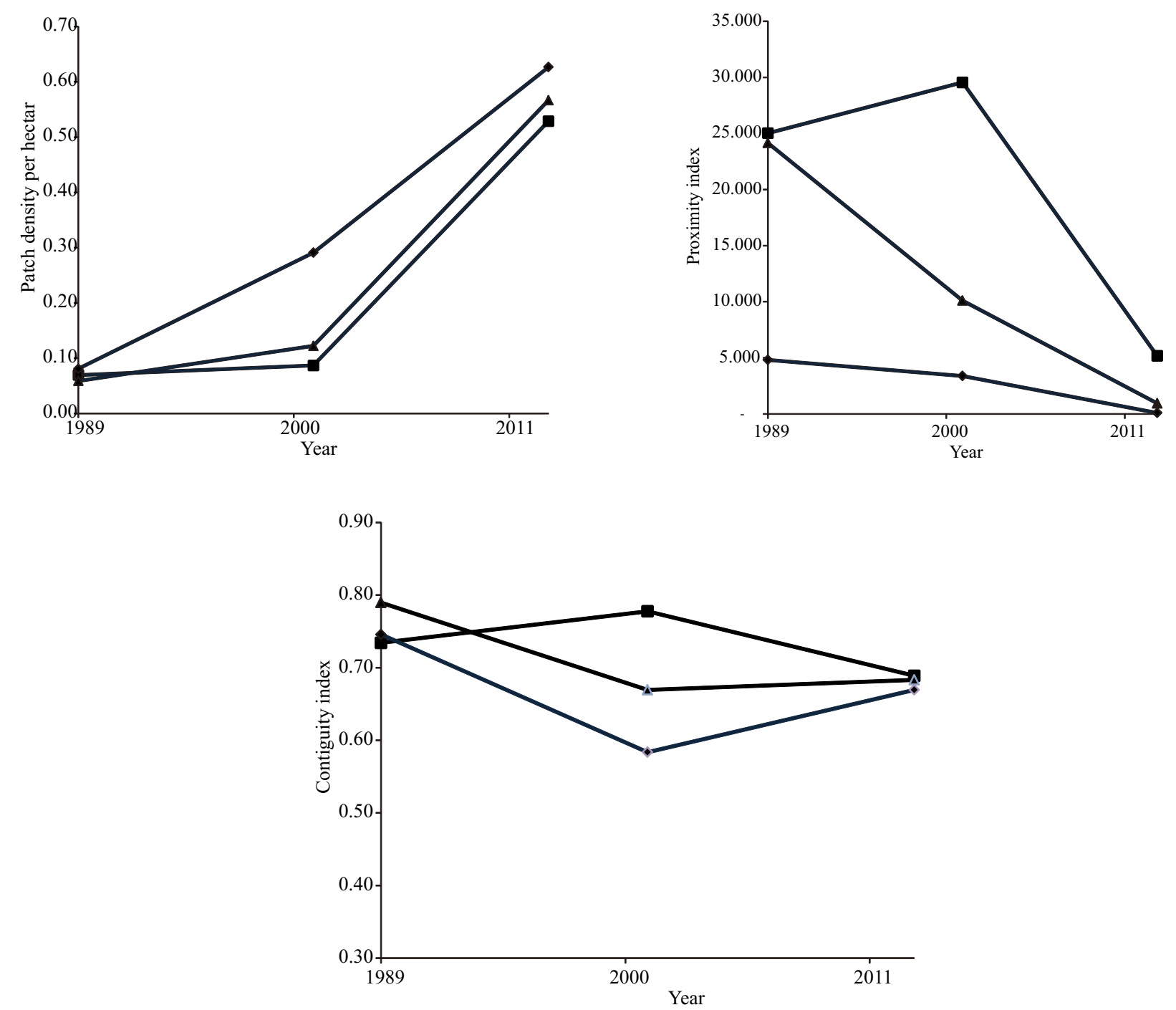

Figure 4 Forest patch density (a), contiguity index (b), and proximity index (c) of each sub watershed. Puli $(\rightarrow)$, Sarula (-1-), Batang Toru Hilir (-+)).

Table 2 Pearson correlations between fragmentation landscape index with distance to the road, distance to the river, degree of slope, and elevation

\begin{tabular}{lcccc}
\hline \multirow{2}{*}{ Sub watershed } & \multicolumn{3}{c}{ Pearson correlation } \\
\cline { 2 - 5 } & Distance to the road & Distance to the river & Slope & Elevation \\
\hline Batang Toru Hilir & $-0.638^{*}$ & $-0.877^{* *}$ & $-0.661^{*}$ & $0.519^{*}$ \\
Puli & $-0.730^{*}$ & $0.993^{*}$ & $-0.556^{*}$ & -0.174 \\
Sarula & $-0.846^{* *}$ & $0.734^{*}$ & $-0.982^{* *}$ & $-0.613^{*}$ \\
\hline
\end{tabular}

$*$ = significant level $0.05 ; * *=$ significant level 0.01 
the higher of index of FLF. Rivers are at a relatively flat area commonly used as a transportation. Positive correlation was found between the index of FLF and distance to the river in sub-watershed of Sarula and Puli. Within this sub-watershed, river is not used as transportation infrastructure due to their area configuration which is steep slope and cliffs. It is so difficult to access a forest in area which is close to river.

Slope affects index of FLF. Pearson correlations show that the higher slope, the lower FLF index and otherwise the lower slope the higher FLF index (Simone et al. 2010). Elevation have no significant correlation with the index of FLF in sub-watershed of Puli, but significant correlation between elevation and the index of FLF occurs in Batang Toru Hilir and Sarula sub-watershed. However, while the higher elevation the higher FLF index in Batang Toru Hilir sub watershed, otherwise the higher elevation the lower of FLF index in sub-watershed of Sarula. This happens because, in sub watershed of Batang Toru, remaining undisturbed of natural forests are at high elevation while the remaining natural forests or plantations at relatively low elevation areas. It get relatively smaller disturbances. So high forest landscape fragmentation tends to occur at higher elevations, because of less monitored in this area.

The road becomes the indirect cause of forest fragmentation and degradation (Simone et al. 2010). The road attracts human for changing land use and land cover. Human will convert forest to agricultural land and get forest product trigger land use changes. More close to the road, forests fragmentation and deforestation increase due to the relationship between forest and human home is easier (Nagendra et al.2003). Development of new road will change forest landscape (Fearnside 2007). Its distribution and pattern follow the road, since the road trigger settlement establishment. Land forest clearing for agriculture was conducted near road and has left only a small part of forest among cleared land (Arima et al. 2005; Feraz et al. 2005; Fearnside 2007). Further, the road increase connectivity among settlement centre that could threat forests sustainability (Fearnside 2008). However, forest in steeply and difficult accessibility area have less human disturbance (Cabral et al. 2007; Munroe et al. 2007). Effective conservation and restoration strategy choice would be well to reinstate the forest (Simone et al. 2010).

The human activities have impact to biodiversity, ecological entities from species to whole communities, and ecosystem (Roy \& Joshi 2002). The vegetation analysis resulted basal area and richness index of Toru Hilir watershed are relatively lower than other watershed. Batang Toru Hilir watershed has value of richness index about 1.27, lower than value richness index of Puli watershed about 1.78. In general, the forest ecosystem within these three sub-watersheds have got moderate exogenous presure having richness index range between 1-2.

Based on the value of clumpiness index, Batang Toru landscape forest is relatively clumped. However, landscape forest in Batang Toru watershed is dominated by small forest patches, while the proportion of large forest patches is relatively low. There is a trend of increasing of the number of forest patches and decreasing of patch size of forest during 1989-2013. This cause increasing of forest landscape fragmentation degree. Correlation between forest landscape fragmentation with biophysics and anthropogenic factor is different among sub-watershed. However, as a broader watersheds ecosystems, forest landscape fragmentation degree is influenced by the distance to the road and the distance to the river. Bigger area and compact forest patches are required in the context of the orang utan habitat. Presently, Batang Toru forest is separated into two blocks that are east block forest and west block forest of Batang Toru. It may cause the orang utan (Pongo abelii) to be isolated from their comunity. For conserving the orang utan habitat, it is needed to restore the habitat. Regaining of the habitat may need a proper planning that have to consider the degree of FLF in and arround project area of rehabilitation.

\section{Conclusion}

Forest landscape pattern of Batang Toru watershed tends to be clumped with landscape structure consisting of relatively small forest patches. The degree of forest landscape fragmentation correlated with distance to the road and distance to the river. The degree of forest landscape fragmentation tend to increase during 1989-2013. High population density can triger forest landscape fragmentation. The high degree of forest fragmentation is mainly occured in downstream of watersheds. Reinstating of forest landscape function should be started with forest landscape having high fragmentation degree.

\section{Acknowledgements}

This research is part of $\mathrm{PhD}$ thesis of the first author funded by SEAMEO-BIOTROP DIPA 2013. The authors extend deeply acknowledgment to the Ministry of Education and Culture-Republic of Indonesia for scholarship and support to accomplish this paper. Sincerely appreciation is also extended to anonymous reviewer for correction and comments.

\section{References}

Arima EY, Walker RT, Perz SG, Caldas M. 2005. Looger and forest fragmentation behaviour model of road building in the Amazon Basin. Annals of the Association of American Geography 95(3):525-541. http://dx.doi.org/ 10.1111/j.1467-8306.2005.00473.x.

Batistella M, Eduardo S, Brondizio, Emilio F, Moran. 2000. Comparative analysis of landscape fragmentation in Rondônia, Brazilian Amazon. International Archives of Photogrammetry and Remote Sensing 33:148-155.

[BPS] Biro Pusat Statistik. 2011. The Village Potential Data (PODES). Jakarta: BPS.

Bradsaw G, Marquet P. 2003. How landuse change; human disturbance and ecosystem fragmentation in the America. Ecological Studies 162:345-353. http://dx.doi.org/10. 1007/978-3-662-05238-9 20.

Cabral DC, Freitas SR, Fiszon JT. 2007. Combining sensors in landscape ecology: imagery based and farm level analysis in study human driven forest fragmentation. 
Sociedade \& Natureza 19(2):69-87. http://dx.doi.org/10. 1590/s1982-45132007000200005.

CBD Secretariat. 2005. Handbook of the Convention on Biological Diversity. Third Edition. Montreal: Secretariat of the Convention on Biological Diversity.

Cox GW. 1985. Laboratory Manual of General Ecology. $5^{\text {th }}$ ed. Dubuque(US): Brown.

Fearnside PM. 2007. Brazil's Cuiabá- Santarém (BR-163) highway: the environmental cost of paving a soybean corridor through the Amazon. The Environmental Management 39(5):601-614. http://dx.doi.org/10. 1007/s00267-006-0149-2.

Fearnside PM. 2008. Will urbanization cause deforested area to be abandoned in Brazilian Amazon? Environmental Conservation 35(3):197-199. http://dx.doi.org/10.1017/s0376892908004906.

Feraz SFB, Vettorazzi CA, Theobald DM, Ballester MVR. 2005. Lanscape dynamic of Amazonia deforestation between 1984 and 2002 in Central Rendonia Brazil: assessment and future scenario. Forest Ecology and Management 204(1):69-85. http://dx.doi.org/10.1016/ j.foreco.2004.07.073.

Forman RTT. 1995. Land Mosaics: The ecology of Landscapes and Regions, 2 Edition. Cambridge: Cambridge University Press.

Forman RTT, Godron M. 1986. Landscape Ecology. New York: Wiley.

Garcia S. 2004. Estimating landscape fragmentation form satellite images; the high of sensor spatial resolution. Remote Sensing for Agriculture, Ecosystem Hydrology. Proceeding of SPIE 5232:668-675.

Giordano F, Boccone N. 2010. Forest fragmentation, urbanization, and landscape structure analysis in an area prone to desertification in Sardinia (Italy). Present Environment and Sustainable Development NR 4:113-128

Fahrig L. 2003. Effect of habitat fragmentation on biodiversity. Annual review of Ecology, Evolution, and Systematic 34(1):487-515. http://dx.doi.org/10. 1146/annurev.ecolsys.34.011802.132419.

Gonzalez-Abraham et al. 2007. Building patterns and landscape fragmentation in Northern Wisconsin, USA. Landscape Ecology 22(2):217-230. http//:dx.doi.org/ 10.1007/s10980-006-9016-z.

Goosem M. 2007. Fragmentation impacts caused by roads through rainforests. Current Science 93:1587-1595.

Gounaridis D, Zaimes GN, Koukoulas K. 2014. Quantifying spatio-temporal patterns of forest fragmentation in Hymettus Mountain, Greece.
Computers, Environment and Urban Systems 46:35-44. http://dx.doi.org/10.1016/j.compenvurbsys.2014. 04.003 .

Hardt E et al. 2013. The influence of natural and anthropogenic landscapes on edge effects. Landscape and Urban Planning 120:59-69. http://dx.doi.org/10. 1016/j.landurbplan.2013.08.014.

[ITTO/IUCN] International Timber Trade Organization/ International Union Conservation Nature. 2005. Restoring forest landscapes. An introduction to the art and science of forest landscape restoration. ITTO Technical Series 23. Yokohama. http://219.127.136.74/ live/Live_Server/1064/ts23e.pdf[12 December 2011].

Jaya INS. 2009. Analysis Citra Dijital: Perspektif Penginderaan Jauh untuk Pengelolaan Sumberdaya Alam. Bogor: Bogor Agricultural University.

Jaya INS, Boer R, Samsuri. 2007. Developing fire risk index in Central Kalimantan. International Research Institute and Bogor Agricultural University. A Project Repport.

Kreb CJ. 1989. Ecological Methology. Columbia: Harper Collins Publisher.

Kusmana C. 1997. Metode Survey Vegetasi. Bogor: Penerbit Institut Pertanian Bogor.

Lamb D, Erskine PD, Parrota JA. 2005. Restoration of degraded tropical forest landscapes. Science 310(5754):1628-1632. http://dx.doi.org/10.1126/ science. 1111773 .

Laurance WF, Goosem M, Laurance SGW. 2009. Impacts of roads and linear clearings on tropical forests. Trends in Ecology and Evolusion 24(12):659-669. http://dx.doi. org/10.1016/j.tree.2009.06.009.

Li M et al. 2009. Asessing rate of forest change and fragmentation in Alabama, USA using the vegetation change tracker model. Forest Ecology and Management 257:1480-1488. http://dx.doi.org/10.1016/j.foreco. 2008.12 .023 .

Liu S et al. 2014. Forest fragmentation and landscape connectivity change associated with road network extension and city expansion: a case study in the Lancang River Valley. Ecological Indicators 36:160-168. http://dx.doi.org/10. 1016/j.ecolind.2013. 07.018

Matsushita B, Xu M, Fukushima T. 2005. Characterizing the changes in landscape structure in the Lake Kasumigaura Basin, Japan using a high-quality GIS dataset. Landscape and Urban Planning 78:241-250. http://dx.doi.org/10.1016/j.landurbplan.2005.08.003.

McGarigal K, Marks BJ. 1995. FRAGSTATS: spatial pattern analysis program for quantifying landscape 
structure. Gen. Tech. Rep. PNW-GTR-351.

McGarigal K, Cushman SA, Neel MC, Ene E. 2002. FRAGSTATS: spatial pattern analysis program for categorical maps. Computer software program produced by the authors at the University of Massachusetts, Amherst. http://www.umass.edu/landeco/research/ fragstats/ fragstats.html. [10 June 2012]

Mendoza E, Fay J, Dirzo R. 2005. A quantitative analysis of forest fragmentation in Los Tuxtlas, Southeast Mexico: patterns and implications for conservation. Revista Chilena De Historia Natura 78:451-467. http://dx.doi. org/10.4067/s0716-078x2005000300008.

Miyamoto A, Sano M. 2008. The influence of forest management on landscape structure in the cooltemperate forest region of central Japan. Landscape and Urban Planning 86:248-256 http://dx.doi.org/ 10.1016/j.land urbplan.2008.03.002.

Munroe DK, Nagendra H, Southworth J. 2007. Monitoring landscape fragmentation in an inaccessible mountain area: Celaque National Park, Western Honduras. Landscape and Urban Planning 83:154-167. http://dx.doi.org/10.1016/j.landurbplan.2007.04.001.

Nagendra H, Southworth J, Tucker C. 2003. Accessibility as a determinan of landscape transformation in Western Honduras. Landscape and Urban Planning 83:154-167. http://dx.doi.org/10.1023/A:1024430026953.

Newman ME, McLaren KP, Wilson BS. 2014. Assessing deforestation and fragmentation in a tropical moist forest over 68 years; the impact of roads and legal protection in the Cockpit Country, Jamaica. Forest Ecology and Management 315:138-152. http://dx.doi.org/10.1016/ j.foreco.2013.12.033.

Default Paragraph Font;Orsi F. Geneletti D. 2010. Identifying priorities area for forest landscape restoration in Chiapas (Mexico): an operational approach combining ecological and socio economic criteria. Landscape and Urban Planning. 94(2010):20-30. http://dx.doi.org/10. 1016/j.landurbplan.2009.07014

Perbatakusuma EA, Damanik A. 2011. Pengelolaan Sumber Daya Alam di Konsesi Usaha Perusahaan Swasta: Penekanan pada Kawasan Bernilai Konservasi Tinggi di Lansekap Hutan Batang Toru-Taman Nasional Batang Gadis. Medan: Konsorsium Ikon Koridor to Sigadis.

Priatna D, Santosa Y, Prasetyo LB, Kartono AP. 2012.
Habitat selection and activity pattern of GPS collared Sumatran Tigers. Jurnal Manajemen Hutan Tropika 18(3):155-163. http://dx.doi.org/10.7226/jtfm.18.3.155.

Reddy CS, Sreeleksmi S, Jha CS, Dahdwal VK. 2013. National assesment of forest fragmentation in India: landscape indices as measure of the effect of fragmentation and forest cover change. Ecology Enginering 60:453-464. http://dx.doi.org/10.1016/j. ecoleng.2013.09.064.

Roy PS, Joshi PK. 2002. Landscape fragmentation and biodiversity conservation. Map India 2002-5th Annual International Conference and Exhibition in GIS, GPS and Remote Sensing, 6-8 February 2002. Pp. 281-285.

Shearman PL, Ash J, Mackey B, Bryan JE, Lokes B. 2009. Forest conversion and degradation in Papua New Guinea 1972-2002. Biotropica 41(3):379-390.

Simone RF. Hawbaker TJ, Jean PM. 2010. Effects of roads, topography, and land use on forest cover dynamics in the Brazilian Atlantic. Forest Forest Ecology and Management 259:410-417. http://dx.doi.org/10.10 16/j.foreco.2009.10.036.

Singh JS, Roy PS, Murthy MSR, Jha CS. 2010. Aplication of landscape ecology and remote sensing for assesment, monitoring and conservatipn of biodiversity. Journal Society of Remote Sensing 38:365-385. http://dx.doi.org/ 10.1007/s12524-010-0033-7.

Thompson J et al. 2002. Land use history, environment, and tree composition in a tropical forest. Ecological Applications 12(5):1344-1363. http://dx.doi.org/10. 1890/1051-0761(2002)012.

Weng YC. 2007. Spatiotemporal changes of landscape pattern in response to urbanization. Landscape and Urban Planning 81(4):341-353. http://dx.doi.org/10.1016/j. landurbplan.2007.01.009.

Wu C, Lin Y, Chiangc L, Huang T. 2014. Assessing highway's impacts on landscape patterns and ecosystem services: a case study in Puli Township, Taiwan. Landscape and Urban Planning. 128:60-71. http://dx.doi.org/10.1016/j.landurbplan.2014.04.020.

Zhang L, Nurvianto S, Harrison S. 2010. Factors affecting the distribution and abundance of Asplenium nidus L. in a tropical lowland rain forest in Peninsular Malaysia. Biotropica 42(4):464-469. http://dx.doi.org/10.1111/ j.1744-7429.2009.00607.x. 